\title{
BUSINESS COMMUNITY STRUCTURES AND URBAN REGIMES: A COMPARATIVE ANALYSIS
}

\author{
MARK DE SOCIO \\ The University of Akron
}

\begin{abstract}
Regime theorists often present business interests as coherent and unified communities with unitary interests. A central principle of regime theory, however, is that business elites tend to occupy privileged positions within regime coalitions because of the scope of resources and expertise they command and cities require for economic development and/or fiscal solvency. Cities are generally home to a wide range of business activities operating at various scales, and business elites representing various corporations in different economic sectors arguably command different kinds of resources and expertise that are functional to the economic activities with which they are affiliated. Various mixes of business elites representing different economic activities might therefore produce differentially biased input regarding urban policy-making and affect the types of regime coalitions that cities develop. Utilizing compilations of interlocking directorates among major organizations across three sectors, profiles of the corporate and social community structures of 24 U.S. cities are generated and a correlation matrix comprised of business and social organizational categories is produced. Factor analysis of the correlation matrix identifies three separate mixes of corporate and social organizational categories that generally conform to descriptions of developmental, caretaker, and progressive regime typologies. These three factors serve as prototypes of the three broad regime types and their corporate community structures. Correlations of the 24 cities with each of the three regime prototypes generally match their regime types as identified through previous case studies. Variations in regime types among cities might therefore be attributed to varying degrees of diversity in the kinds of corporations headquartered or located within them. Closer attention to the economic base of cities-the producers, after all, of local business elites-may reveal internal biases and/or material predisposition towards some urban policies over others by local business elites in relation to the economic activities with which they are linked.
\end{abstract}

\section{INTRODUCTION}

In a thoughtful reflection on the status of urban regime theory, which currently reigns "as the dominant paradigm in the analysis of urban governance" and has so for "more than a decade," Imbroscio (2003, pp. 271-272) suggests that urban regime theory might be further strengthened "by engaging economic issues with a greater degree of seriousness and rigor." Imbroscio's (2003,

Direct Correspondence to: Mark de Socio, Department of Geography and Planning, Buchtel College of Arts and Sciences, The University of Akron, Akron, $\mathrm{OH}$ 44325-5005.E-mail: desocim@ uakron.edu.

JOURNAL OF URBAN AFFAIRS, Volume 29, Number 4, pages 339-366.

Copyright $(2007$ Urban Affairs Association

All rights of reproduction in any form reserved.

ISSN: 0735-2166. 
p. 275) own proposal for engaging economic issues entails a focus on "alternative ideas about the nature of city economies and how to promote their vitality." In previous work (Imbroscio, 1998, p. 238), this involves a focus on the entrepreneurial potential of the local state, particularly if the local state is mobilized on behalf of interests more progressive than typical corporate interests. Concurrently, Imbroscio (2003, p. 276) promotes six building blocks through which to engage in a "new alternative economic paradigm" that would ostensibly enable scholars to break with traditional understandings of urban economies and imagine more innovative and inclusionary political arrangements.

While Imbroscio's reflection has inspired further debate and theoretical refinement regarding urban regime theory's normative thrust (Davies, 2004; Imbroscio, 2004; Rast, 2005; Stone, 2004), Imbroscio's general call for sustained and systematic attention to urban economies in relation to urban politics inspires a different approach taken here. Whilst regime theorists imagine more equitable political arrangements by exploring supposed "progressive" impacts of certain civic and/or social organizations as they engage with other actors-for example, always-present business interests-in political coalition-building (Kilburn, 2004, p. 635; Mossberger \& Stoker, 2001, p. 816; Orr, 1992; Stone, 2001), these same business interests are most often presented as coherent and unified communities with unitary interests (Austin \& McCaffrey, 2002, p. 36). Even Stone's (1989, pp. 168-173) seminal work on the nature of urban regimes presents Atlanta's business community as largely unified. A central principle of regime theory, however, is that business elites tend to occupy privileged positions within regime coalitions because of the scope of resources and expertise they command and cities require for economic development and/or fiscal solvency (Dowding, 2001, p. 8; Elkin, 1987; Stone, 1980). Cities are generally home to a wide range of business activities operating at various scales, and business elites representing various corporations in different economic sectors arguably command different kinds of resources and expertise that are functional to the economic activities with which they are affiliated. Various mixes of business elites representing different economic activities might therefore produce differentially biased input regarding urban policy-making and affect the types of regime coalitions that cities develop. Closer attention to the economic base of cities - the producers, after all, of local business elites-may reveal internal biases and/or material predisposition towards some urban policies over others by local business elites in relation to the economic activities with which they are linked.

Civic groups and social organizations in governing coalitions, like BUILD in Baltimore (Orr, 1992) or EPISO in El Paso (Stone, 2004), clearly make their mark on regime orientations by affecting the kinds of policies pursued when they are included in governing coalitions (Kilburn, 2004 , p. 635). The question is whether various mixes of business elites also stamp distinctive politics on governing coalitions. The primary objective of this article is thus to explore whether variation in prevailing regime orientations in U.S. cities correspond to different configurations of business elite representation.

\section{COMPARATIVE ANALYSIS}

A secondary objective is to forward an approach that enables systematic comparative analysis of urban regimes. Much of regime theory explores the political nature of regime coalitions and coalition building, which demands a "holistic and context-embracing approach to understand the contemporary city or the historical trajectory of urban development" (Pierre, 2005, p. 447). However, questions of variation in regime composition, formation, maintenance, or change require a comparative approach that has proved quite difficult given the nature of regime theory's localist formulation. Key components of the urban regime concept—-for example, that regime coalitions 
are "largely informal, contain identifying agendas, display stable arrangements over long periods of time, and have a 'productive character" (Stone, 2001, p. 21)—demand intensive long-term inquiry into the processes and contexts of regime formation and maintenance, making case studies the methodology of choice among regime scholars.

This poses a problem for comparative studies exploring variation in regime formation, maintenance, or character. Reliance upon interviews and archival data over a period of many years as the primary methodological tool for case studies is problematic for comparative analyses across several cities (Gissendanner, 2003, p. 665). Only two or three cities can be adequately compared using the traditional case-study approach; anything beyond that is unwieldy (Kilburn, 2004, p. 635). Consequently, regime theory as practiced thus far is limited in its ability to explain variation in regime formation or policy orientation (Gissendanner, 2003, p. 664).

One challenge facing urban regime scholars comparing multiple cities is identifying "common categories, concepts or variables that can be measured" (Kantor \& Savitch, 2005, p. 136; see also Mossberger \& Stoker, 2001, p. 814). A Millsian conceptualization of elites, however, views business and political elites and community and social leaders as linked to locally-based institutions such as corporations and government, or community, business and neighborhood organizations (Mills, 1956). This structural view-that elite status is institutionally-bound (Stone, 2001, p. 22) - offers a window through which to explore common categories and variables among a wide range of cities, at least within a single national context. In the United States, for example, such institutions and organizations are required by federal law to report earnings, assets, outlays, and the like to various regulatory bodies. For corporations and public-private partnerships, the U.S. Securities and Exchange Commission (SEC) is perhaps the most prominent regulatory authority with whom they must file various reports. One report, the $10-\mathrm{K}$ filing (commonly referred to as the "annual report"), contains overviews of corporate and organization information like addresses of headquarters and other facilities, net sales, expenses, identification of corporate officers and directors, and other variables.

\section{INTERLOCKING DIRECTORATES}

Corporate directors and upper-rank officers are recognized by students of community power structure and organizational network theory as members of the local business, social or political elite (Domhoff, 1967, 1970; Hunter, 1953, pp. 61-111; Moore et al., 2002; Schoenberger, 1991, 2001; Scott, 2003; Useem, 1984, pp. 38-40). Particularly active elites are known to sit on more than one corporate or other institutional board, and often across sectors, forming linkages between companies and organizations through shared, or "interlocking," directorates (Harding, 2000; Useem, 1984, pp. 38-40). The sheer pervasiveness and longstanding tradition of interlocking directorates within and across the spectrum of corporations, civic organizations, and public-private partnerships in capitalist societies has attracted the attention of social scientists and theorists for several decades. Interest among scholars regarding interlocking directorates has traditionally focused on two main questions: (1) what motivates companies and organizations to seek interlocks with other corporations and organizations, and (2) what are the impacts of interlocking directorates on corporate and organizational performance.

Various theoretical explanations for interlocking directorates and their impacts have been advanced over the years. These include models of resource dependency, bank control, legitimacy, and social cohesion. The four models are generally complementary, and each is briefly described below. The section concludes with a discussion on the role of the chief executive officer (CEO) in shaping boards of directors and establishing inter-firm interlocks, and the relationship between CEOs and corporate boards in general. 


\section{Resource Dependency}

The resource dependency model suggests that firms establish interlocks as a means to exercise some degree of control over other firms with which they are interdependent, such as suppliers, purchasers, or financial institutions (Burt, 1980; Davis \& Mizruchi, 1999; Galaskiewicz, 1985; Pfeffer, 1987). The need for some measure of control arises from increasingly complex and competitive market environments within which firms and organizations operate, increased interdependencies among firms, and "market imperfections" such as uncertainty and asymmetrical power dependencies (Galaskiewicz, 1985, p. 282; Pfeffer, 1972a; Pfeffer, 1987; Storper \& Walker, 1989, pp. 79-82).

\section{Bank Control}

The bank control model, a variant of the resource dependency model, finds that financial institutions tend to enjoy a high degree of centrality among interlocked firms, particularly manufacturing firms. Bank centrality is based on "their ability to grant or refuse loans to major firms" (Mintz \& Schwartz, 1983; Mintz \& Schwartz, 1985, p. 28). By refusing or guaranteeing loans on their own terms, banks can exercise some control over management decision-making in ways that enhance the financial interests of the banks themselves $v i s-\grave{a}$-vis the commercial interests of their clients (see Mintz \& Schwartz, 1985, pp. 39-44 for a thorough consideration of bank control theory through a review of relationships between financial firms and airlines). Other studies find that high bank centrality among interlocked firms occurs because they demand inclusion with firms that are in distress and experiencing low performance and debt in order to monitor and protect their investments (Lang \& Lockhart, 1990; Mizruchi \& Stearns, 1988; Pfeffer, 1972b, p. 222). More recently, studies have found that banking firms experienced a reduction in centrality among interlocked firms in the 1980s and 1990s due to technological advances and market deregulation in the financial and banking industries that allowed for alternative methods of financing for corporations (Barnes \& Ritter, 2001; Davis \& Mizruchi, 1999). Consequently, major enterprises are able to rely upon various financial institutions for short-term loans and other capital. Nevertheless, financial institutions, while diverse, often share overlapping interests and are deemed able to exercise some degree of control over large enterprises via a "constellation of interests" (Scott, 1991, p. 190).

\section{Legitimacy}

The legitimacy model contends that companies, particularly newly established companies, and civic groups and philanthropic organizations seek to recruit established executives and managers from other reputable companies and organizations to serve as directors in order to legitimize the company or organization (Boyle \& Silver, 2005; Galaskiewicz \& Bielefeld, 1998, p. 19; Mizruchi, 1996). Potential investors, suppliers, or customers would, it is argued, have greater trust in a company or organization with recognized and respected leaders represented on its board.

\section{Social Cohesion}

Models of social cohesion focus on the structure of social relations within which firms are embedded by exploring connections between, and engendered by, company directors (Brayshay, Clearly, \& Selwood, 2005, p. 210). Corporate communities operate within complex sets of networks and contacts embodied by interlocking directorates that create social relations between two 
or more firms (Galaskiewicz \& Bielefeld, 1998, p. 18; Scott, 1991, p. 182). The more widely-cast the network of interlocked firms, the more complex is the web of social relations within which firms are embedded.

Studies of social cohesion draw heavily from community power structure and network theory where the social backgrounds of individual directors are explored. Top corporate officers and directors generally share similar educational and social backgrounds like attending certain exclusive schools and universities, being members of particular social clubs, being members of renowned capitalist or celebrity families, and having accrued (largely, but not exclusively, through inheritance) some substantial measure of wealth (Burris, 1991; Domhoff, 1967, 1970, 1980; Hunter, 1953; Mills, 1956; Mizruchi, 1996, p. 279; Useem, 1979, 1980, 1984). Directors are widely recognized as constituting an economic elite and as representatives of a capitalist class; the main purpose for interlocks, some argue, is to influence corporate and other institutional decision-making in pursuit of their own class interests (Domhoff, 1967, 1970, 2006; Mills, 1956; Mizruchi, 1996; O’Hagan \& Green, 2004, p. 129; Useem, 1984, pp. 38-45).

As a structure of social cohesion among representatives of the capitalist class, interlocking directorates facilitate information exchange and communication among directors. While the Clayton Act of 1914 explicitly prohibits direct interlocks between competing firms in order to limit the potential for collusion, indirect interlocks - those where different corporations and organizations are linked together by membership on a third board-are not prohibited (Finch \& White, 2005, p. 175; Lyson \& Raymer, 2000, p. 204). Information and knowledge can therefore pass among directors representing a wide range of firms and organizations, including among competitors.

Both explicit knowledge, like new technologies, production processes, or management styles, and tacit knowledge, may be exchanged. Tacit knowledge "is highly subjective, less teachable and less observable. Its ambiguous nature makes it difficult to process and communicate. With few exceptions, tacit knowledge can only be learned through face-to-face communication" (O'Hagan \& Green, 2002, p. 155). Tacit knowledge includes, among other things, knowledge of foreign economic affairs, "learning about the practice and experiences of another large company, and hearing about the policies of still other companies," and knowledge of the general business environmentall gained through personal contacts among interlocked directorates (Lorsch \& MacIver, 1989, p. 27; Useem, 1984, p. 46). Even where no interdependency between interlocked firms exists as the resource dependency model would suggest, general information regarding a company's management, labor, market, or production problems — and the company's responses-prove invaluable to other companies.

In social cohesion models, firms would be expected to act in ways that suggest information exchange between two or more firms. Indeed, numerous studies seeking evidence of information and knowledge exchange among interlocked firms have been conducted and yielded various results (Everard \& Henry, 2002; Galetkanycz \& Hambrick, 1997; Green \& Semple, 1981; Haunschild, 1993; Lyson \& Raymer, 2000; Mintz \& Schwartz, 1985). ${ }^{1}$ In addition to market behavior, social cohesion among interlocking directorates has ramifications for the corporate exercise of political power. Useem (1984, p. 146) argues that the dual nature of interlocking directorates as both a network of firms and as a social network of members of the business class means that firms are driven by two separate but interrelated logics: an internal market-based logic of the firm and social class logic. For policy areas such as issue advertising, political underwriting, and charitable giving - those issues most defining of a corporation's "public face"- social class influence is often the driving force (Useem, 1984, p. 146). Class considerations affect decisions such as what topics are to be covered by editorials, which political candidates are selected for financial backing, and which organizations are chosen for company philanthropy or other eleemosynary activities (Burris, 1991; Mills, 1956; Mintz \& Schwartz, 1985, p. 141; Stone, 1989, p. 173; Useem, 1984, p. 146 ). 
Not all business leaders, however, are active in local or national policy-making, nor does serving as a top corporate manager, chief executive, or director automatically confer classconsciousness or political status (Useem, 1984, p. 1). Instead, proving one's management and organizational skills by successfully leading a large institution, and demonstrating an ability to recognize, articulate, and act upon the general interests of the business class as a whole rather than one's own specific corporation's or industry's interests is the true measure of membership in the small club of influential men and women (Stone 1989, p.170; Useem, 1984, pp. 102-106). This small club represents an "inner circle" of elites who have been further socialized to represent and pursue the interests of the business or corporate class in national and local policy-making (Harvey, 2005, p. 33; Mintz \& Schwartz, 1985; Mizruchi, 1992; Ratcliff, 1980; Useem, 1984). This is the group who are called upon to serve on multiple boards of directors among various corporations and organizations and form ties between them.

Requisite skills identified by Useem (1984, pp. 102-106) for inclusion in the "inner circle"like successful management of large institutions-suggests that only the most senior and experienced corporate officers make the cut. Finch and White (2005, p. 176) note that among large corporations in the United States in 1991, one firm in seven was involved in direct reciprocal interlocks involving the most senior of corporate officers: CEOs. Useem $(1984$, p. 48) and Lorsch \& MacIver (1989, p. 18) report that more than half of all board members in the United States are CEO of a corporation. This suggests that CEOs not only play a central role in the shaping of both board composition and board activities (Demb \& Neubauer, 2002, p. 137; Finch \& White, 2005, p. 193; Lorsch \& MacIver, 1989, pp. 20-22; Pfeffer, 1972b, p. 220), but also seek directors who share similar experiences and challenges within their own firms (Lorsch \& MacIver, 1989, pp. 18-19; Westphal \& Zajac, 1995). As for outside directors who are CEO of their own firms, Lorsch and MacIver (1989, pp. 27-28) find that such individuals most often cite the opportunity to observe and learn from their peers as the primary reason for accepting outside board appointments.

A major role of the board of directors is to generally support the goals and policies of the CEO (Anderson \& Anthony, 1986, p. 3; Lorsch \& MacIver, 1989, p. 64; Mace, 1971, pp. 10-42). While boards of directors have the ultimate responsibility of removing a CEO if his or her performance is judged to be detrimental to the firm, the CEO generally enjoys much flexibility in shaping and leading a firm's business strategies. Hence, a CEO instilled with the value of, for example, the arts, can shape company policies towards sponsorship and funding of a city's arts community (Useem, 1984, p. 146). The probability, however, "that a given company is led by such an individual is affected by the firm's ties to the corporate community" (Useem, 1984, p. 146). The more embedded a firm is within the network of interlocked firms, "the more likely is the company to be guided by those who believe they must play a leadership role larger than that required by the firm's quest for profits - and that their role must begin at home. This translates into directing their own firms to underwrite charitable causes, start political action committees, and act in ways the corporate community would define as socially responsible" (Useem, 1984, p. 146).

The most active of corporations in political matters are typically those guided by CEOs at the center of interlocking directorates. The aggregate of directorates comprising the network of interlocked firms and organizations represent the full range of skills and resources available to CEOs for political mobilization. In order to address whether different mixes of director affiliations bias the political orientation of participatory business leaders towards some urban policies over others, directors and their primary affiliations must be identified and analyzed across a range of localities. 


\section{CATEGORIZING DIRECTOR AFFILIATIONS}

Directorship lists are publicly available through annual reports. Consequently, annual reports can serve as a trove of common concepts, categories and variables for comparative regime analyses. This study utilizes directorship lists from the annual reports of all major institutions across several cities to explore whether variation in regime orientations correspond to different mixes in the kinds of businesses represented on cities' leading boards of directors.

All publicly traded corporations, public-private partnerships, and civic organizations are required to have independent oversight. Boards of directors serve this purpose (CarminattiMarchand \& Paquerot, 2001; Loderer \& Peyer, 2002; Roberts \& Murray, 2002; Schoenberger, 2001). Through annual reports, corporations and organizations provide biographical data on board members. Typical information includes the individual's name and institution with whom he or she is affiliated, the individual's official title or capacity within his or her affiliation, other institutions where the individual may be serving as a director, and other data. Since elite status is conceptualized here as being institutionally-bound, and we are interested in whether variation in regime typologies among cities corresponds to different mixes of business elites represented among interlocked firms and organizations, then it is the affiliation of directors that are to be categorized. Categorizing directors' affiliations involves determining the sectors to which they belong. Director affiliations typically span three broad sectors of social, political, and economic institutions (Harding, 2000; Pierre, 2005, p. 453; Stone, 2001, p. 21).

For the economic sector, several institutions, both public and private, categorize economic activities for various purposes. Some categorizations are very specific, like NAIC codes provided by the U.S. Department of Commerce, while others are more general, such as those used by Fortune Magazine. For example, Fortune Magazine would place a chemical-producing firm under the category of "chemicals." Several NAIC codes may be attributed to the same chemical producer, however, to depict specific types and applications of various chemicals produced by the firm. For this study, Fortune magazine's categories (Table 1) are preferred because the degree of specificity of NAICS codes is too cumbersome for comparative analyses across a range of firms. Accordingly, the function of each director's affiliation was evaluated and labeled using the most comparable Fortune Magazine category. Local and national business directories were consulted where necessary to aid in the categorization process.

In addition to those affiliated with economic activities and their numerous categories, other directors may be affiliated with the social and political sectors comprised of government, universities, philanthropic organizations, community foundations, public-private partnerships, neighborhood organizations, or other institutions. To account for these groups, this study consolidates remaining affiliations into five additional categories: civic, developmental, education, government, and military (Table 1). The category of "civic" includes neighborhood, philanthropic, civil rights, environmental, and other organizations whose shared interests is generally the enhancement of spatial use values and quality of life (Cox, 1995; Logan \& Molotch, 1987). The category of "education" refers to universities, "developmental" refers to public-private partnerships such as development authorities or business roundtables organized to offer business input for government policy-making (Harding, 2000), and "government" refers to any government agency or office at any scale, both foreign and domestic. Finally, the category of "military" encapsulates directors whose affiliations list any branch of the U.S. military.

Data collection for this study occurred from March through October 2004. Twenty-four U.S. cities representing each of the U.S. Census Bureau regions were selected for the purpose of exploring whether variation in prevailing regime orientations correspond to different mixes of business elites (Table 2). Fifteen of the twenty-four cities were previously case-studied and their 
TABLE 1

Categories of Board Member Affiliations, in alphabetical order

\begin{tabular}{ll}
\hline No. & Category Nomenclatures by Fortune Magazine \\
\hline 1 & Accounting services \\
2 & Aerospace \& defense \\
3 & Banking \\
4 & Business services \\
5 & Business supplies \\
6 & Capital goods \\
7 & Chemicals \\
8 & Computers-software \& services \\
9 & Computers \& electronics \\
10 & Construction \\
11 & Consumer durables \\
12 & Energy \\
13 & Entertainment \& information \\
14 & Financial services \\
15 & Food distributors \\
16 & Food, drink \& tobacco \\
17 & Forest products \& packaging \\
18 & Health care \\
19 & Household \& personal products \\
20 & Insurance \\
21 & Internet \\
22 & Legal services \\
23 & Metals \\
24 & REIT \\
25 & Retailing \\
26 & Telecommunications \\
27 & Travel \& transport \\
No. & Additional categories \\
\hline 28 & Civic \\
29 & Developmental \\
30 & Education \\
31 & Government \\
32 & Military \\
\hline & \\
\hline
\end{tabular}

regimes or governing coalitions characterized (Table 3). These case studies serve as authoritative benchmarks for which to compare findings (Gissendanner, 2003; Kantor \& Savitch, 2005, p. 148; Kilburn, 2004). An additional nine cities were included for the purpose of testing the robustness of the technique (Table 4).

Identification of all major corporations, civic groups, foundations, and public-private partnerships for the purpose of categorizing their directors' affiliations took place as follows. For corporations, those ranked in the top 1,000 in 2003 revenue by Fortune Magazine, and companies that employ 5,000 or more workers, were selected. Fortune Magazine is a widely read and highly respected international commercial publication that reports on major economic trends globally. To be a Fortune-ranked company (in terms of ranking by revenue or other criteria) is widely considered to be a prestigious achievement for corporations and their employees. Some of the twenty-four cities are home to only one or two Fortune-ranked companies, however, so the criterion for selecting companies was widened to include the largest employers (at least five thousand employees) to ensure that at least four major corporations were selected for each city to allow for comparative analysis. 
TABLE 2

\section{Study Area}

\begin{tabular}{ll}
\hline City & \multicolumn{1}{c}{ Region } \\
\hline Boston & New England \\
Charlotte & South Atlantic \\
Chicago & East North Central \\
Cincinnati & East North Central \\
Cleveland & East North Central \\
Dallas & West South Central \\
Denver & Mountain \\
Houston & West South Central \\
Indianapolis & East North Central \\
Kansas City & West North Central \\
Los Angeles & Pacific \\
Miami & South Atlantic \\
New Orleans & West South Central \\
New York & Middle Atlantic \\
Norfolk & South Atlantic \\
Orlando & South Atlantic \\
Philadelphia & Middle Atlantic \\
Phoenix & Mountain \\
Pittsburgh & Middle Atlantic \\
Saint Louis & West North Central \\
Salt Lake City & Mountain \\
San Antonio & West South Central \\
San Diego & Pacific \\
Tampa & South Atlantic \\
\hline
\end{tabular}

Note: Regions defined by U.S. Census Bureau.

TABLE 3

Cities and Case Studies in Urban Regime Theory Literature

\begin{tabular}{|c|c|c|}
\hline City & Regime typology & Case studies \\
\hline Boston & Progressive & Ward (1996) \\
\hline Charlotte & Developmental & Smith and Graves (2005) \\
\hline Chicago & Developmental & $\begin{array}{l}\text { Bennett et al. (1988), Mier, Moe, and Sherr (1986), } \\
\text { Ferman (1996) }\end{array}$ \\
\hline Cincinnati & Developmental & $\begin{array}{l}\text { Salmon and Leibovitz (1999), Brown and Paul (2000), } \\
\text { Austrian and Rosentraub (2002) }\end{array}$ \\
\hline Cleveland & Developmental & Austrian and Rosentraub (2002) \\
\hline Dallas & Developmental & Elkin (1987) \\
\hline Houston & Developmental & $\begin{array}{l}\text { Kirby and Lynch (1987), Feagin }(1985,1988), \text { Parker } \\
\text { and Feagin (1990) }\end{array}$ \\
\hline Indianapolis & Developmental & Austrian and Rosentraub (2002) \\
\hline New Orleans & Caretaker & $\begin{array}{l}\text { Whelan (1987), Whelan and Young (1991), } \\
\text { Whelan, Young, and Lauria (1994), Ward (1996) }\end{array}$ \\
\hline New York & Developmental & Whitt (1987) \\
\hline Philadelphia & Developmental & Jo $(2002)$ \\
\hline Pittsburgh & Developmental & Ferman (1996), Jo (2002) \\
\hline St. Louis & Developmental & Glassberg (1991) \\
\hline Salt Lake City & Caretaker & Andranovich, Burbank, and Heying (2001) \\
\hline Tampa & Progressive & Kerstein (1993), Turner (1992) \\
\hline
\end{tabular}


TABLE 4

Expected Regime Types, and Justification for Expected Regime Types, for Non-Case Studied Cities

\begin{tabular}{lll}
\hline City & Regime typology & \multicolumn{1}{c}{ Justification } \\
\hline Denver & Progressive & Kerstein (1993), Turner (1992) \\
Kansas City & Developmental & Glassberg (1991) \\
Los Angeles & Progressive & Kerstein (1993), Turner (1992) \\
Miami & Progressive & Kerstein (1993), Turner (1992) \\
Norfolk & Caretaker & Significant presence of military bases \\
Orlando & Progressive & Kerstein (1993), Turner (1992) \\
Phoenix & Progressive & Kerstein (1993), Turner (1992) \\
San Antonio & Caretaker & Significant presence of military bases \\
San Diego & Caretaker & Significant presence of military bases \\
\hline
\end{tabular}

Aside from traditional eleemosynary organizations such as United Way and community foundations found in each of the twenty-four cities, the selection of development agencies and civic organizations was based primarily on identifying agencies and organizations included within the networks of interlocked directorates among corporations and by cross-referencing listed affiliations of directors. Firms consistently list other firms and organizations for whom their inside and outside directors also serve as either directors or managers. Civic organizations, foundations, business roundtables, arts organizations, public-private partnerships, and the like, were often listed as secondary or tertiary affiliations, and in some cases, the primary affiliation, for interlocked directors. Indeed, much of the literature on relationships between the non-profit sector and the corporate sector find strong linkages between firms and large cultural institutions through interlocking corporate directors and organizational and university trustees-and for similar reasons as corporate interlocks (i.e., resource dependency, legitimacy, and social cohesion) (DiMaggio \& Anheier, 1990, p. 141; Galaskiewicz \& Bielefeld, 1998, p. 18; Martin, 2004; Salzman \& Domhoff, 1980, pp. 232-238; Salzman \& Domhoff, 1983, p. 141). Outside of the database of interlocked firms and organizations, other non-corporate organizations and institutions were discovered by reviewing business journals and newspaper articles from each of the twenty-four cities and through exploring the websites of city governments, development organizations, chambers of commerce, and other government and public-private partnership entities. Finally, some organizations were discovered through academic journal articles referring to their roles in certain projects.

It is important to note that organizations not interlocked with the corporate sector would be considered peripheral to the networks of business elites (Useem, 1984, pp. 141-147). However, neighborhood groups, religious organizations, or issue groups, while generally smaller in organization and representing more localized constituencies nevertheless can have profound impacts on urban politics as demonstrated by Stone (1989, pp. 67-73). This is where academic journals and newspaper accounts were important in identifying such groups having an impact on urban politics. Nevertheless, given their generally small size and status as peripheral to networks of business elites, it is quite possible that some organizations may have been overlooked, thus possibly skewing our results in some cases.

\section{METHODOLOGY}

In a recent comparative study of U.S. urban regimes, Kilburn (2004) used qualitative comparative analysis (QCA) to measure the impacts of combinations of three urban structural features in producing progressive regimes: the fiscal base, democratic conditions (ward-style city council representation, and degree of civic participation), and the presence of export-oriented economic firms. This study, however, focuses specifically on the social agency of business elites. Interlocking 
directorates embody the social cohesion of business elites and the aggregate of resources at their command. Interlocking directorates across the twenty-four cities comprise a total seat count of 10,491. Understanding how different configurations of economic affiliations among the 10,491 seats may be related to different political orientations of the group is a question for which factor analysis is uniquely applicable. Essentially a data reduction technique, factor analysis allows one to "identify and summarize the many inter-relationships that exist among individual variables," particularly among a large number of variables (Kachigan, 1991, p. 236). Factor analysis is a procedure for eliminating redundancy among a large set of correlated variables, and separating variables into groups of similarities. Accordingly, exploratory factor analysis is used to identify families of strong correlations among directorship affiliations for which to compare against profiles of directorship affiliations for each of the twenty-four cities indicating the ratio of specific directorship affiliations per each city's total board seat count.

A data matrix was constructed indicating the number of directorships per affiliation category for each of the twenty-four cities (Table 5). The grand total of directorships or "seats" across the twenty-four cities is 10,491. Profiles of directorship affiliations for each of the twenty-four cities were created indicating the ratio of specific directorship affiliations per each city's total seat count (Table 6), and correlation was performed among the directorship affiliation categories (Table 7). A careful visual examination of the correlation matrix for category variables produces two broad observations. First, the vast majority of the correlations are positive and in the mid-to-high level range of correlation coefficients. Second, there appears to be a clear distinction among servicebased categories such as banking, business services, financial services, and government on the one hand, and more blue-collar and manufacturing-based categories such as capital goods, chemicals, and consumer durables on the other. The service-based category variables share relatively high correlations among themselves, as do the manufacturing-based category variables, but the two sets have very low correlations when compared to each other. This observation is borne out further by city profiles where those with high director affiliation representations of capital goods, chemicals, and consumer durables have lower affiliation representations of service-sector categories, and vice-versa.

A factor analysis of the category correlation matrix reinforces these observations. A varimax rotation produces the most pronounced differences between clusters of closely associated directorship affiliation categories, drawing out three main factors that each explain a reasonable degree of the common variance: $29.6 \%$ (factor one), $25.3 \%$ (factor two), and $21.3 \%$ (factor three), and a cumulative variance of $76.2 \%$ (Table 8 ). A review of the factor loadings (Table 8 ) reinforces the clear distinction between service-based and manufacturing-based director affiliations, with the former (e.g., accounting services, banking, business services, and real estate) scoring highest in Factor 2 and the latter (e.g., capital goods, chemicals, consumer durables, forest products \& packaging) in Factor 3.

Typologies of regimes described in the literature are too numerous and varied to be reviewed here (see DiGaetano \& Klemanski, 1989; Dowding, 2001; Fainstein et al., 1983; Kilburn, 2004; and Ward, 1996, for a range of typology characterizations). However, a review of the directorship affiliation categories grouped among the three main factors appear to correspond to three broad regime typologies presented by Dowding (2001), Kilburn (2004), and Ward (1996) as encapsulating the general themes and policy orientations of other regime characterizations. These three broad typologies are developmental, caretaker, and progressive.

Developmental regimes generally promote economic development (Dowding, 2001, p. 13; Kilburn, 2004, p. 635; Stone, 1993; Ward, 1996). Caretaker regimes generally maintain a lasseiz faire approach to economic development and instead promote a policy focus on traditional municipal service provision (Harvey, 1989; Stone, 1989, p. 188). Progressive regimes promote opportunity expansion for working class and minority populations, or they promote policies that 


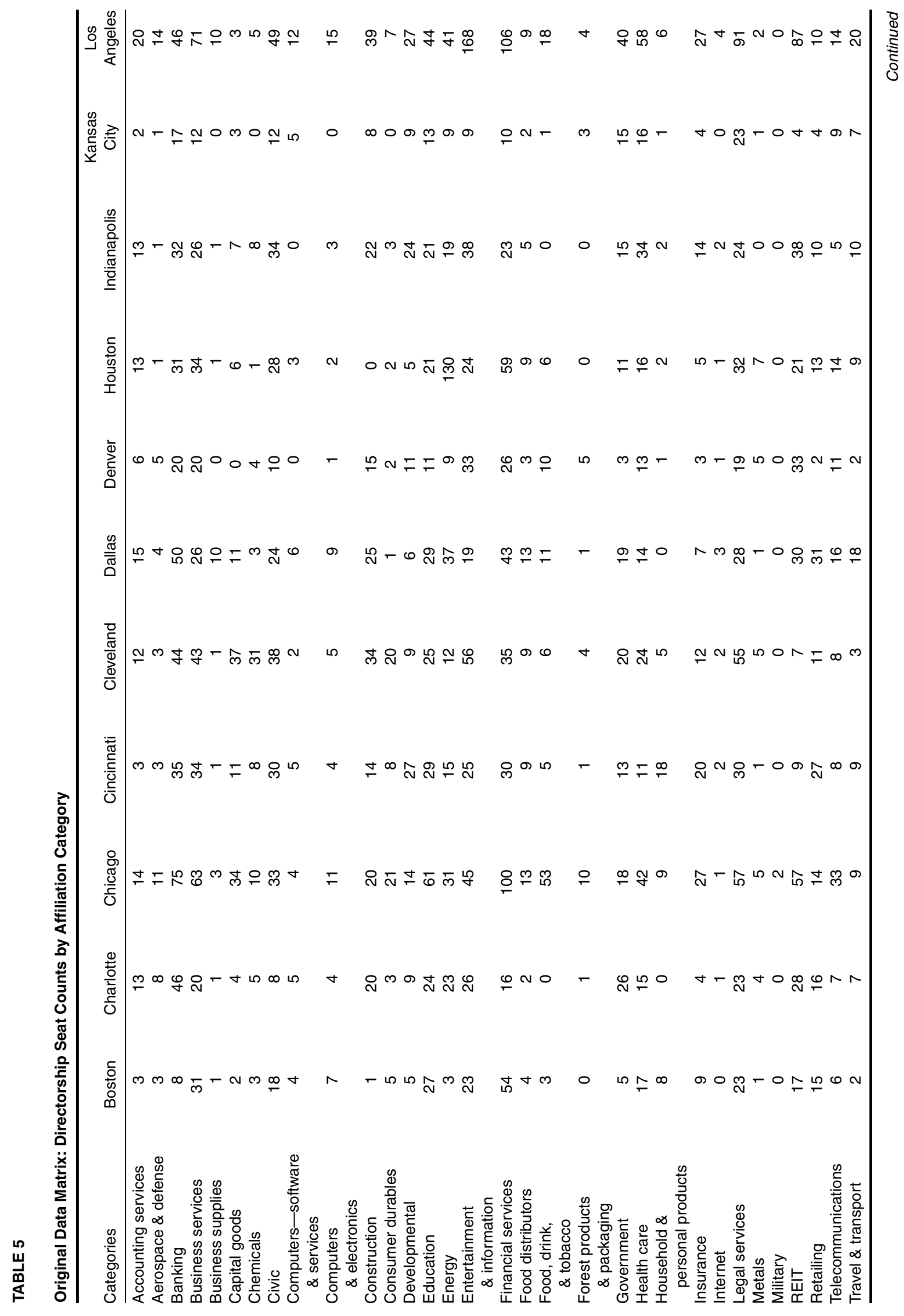




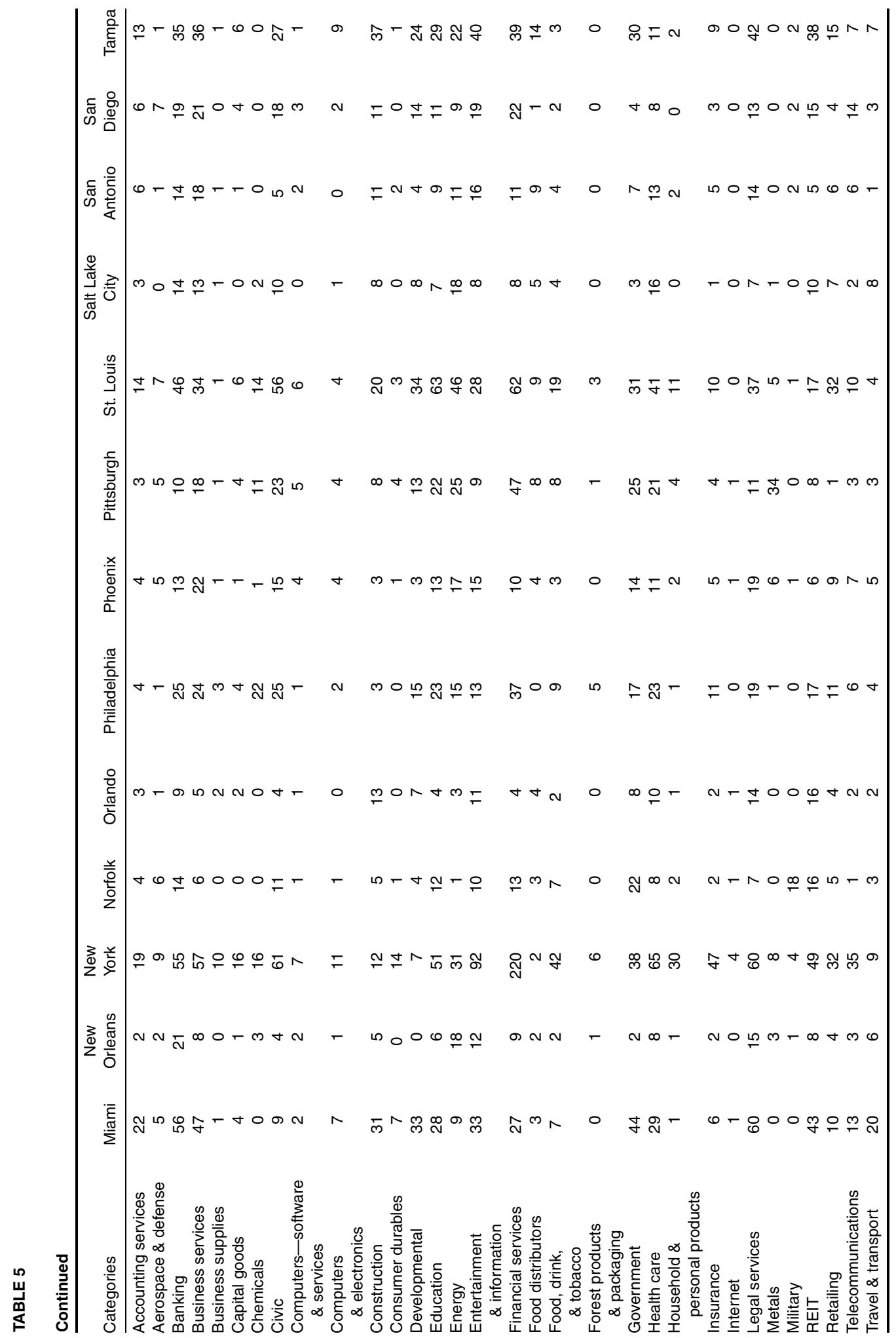




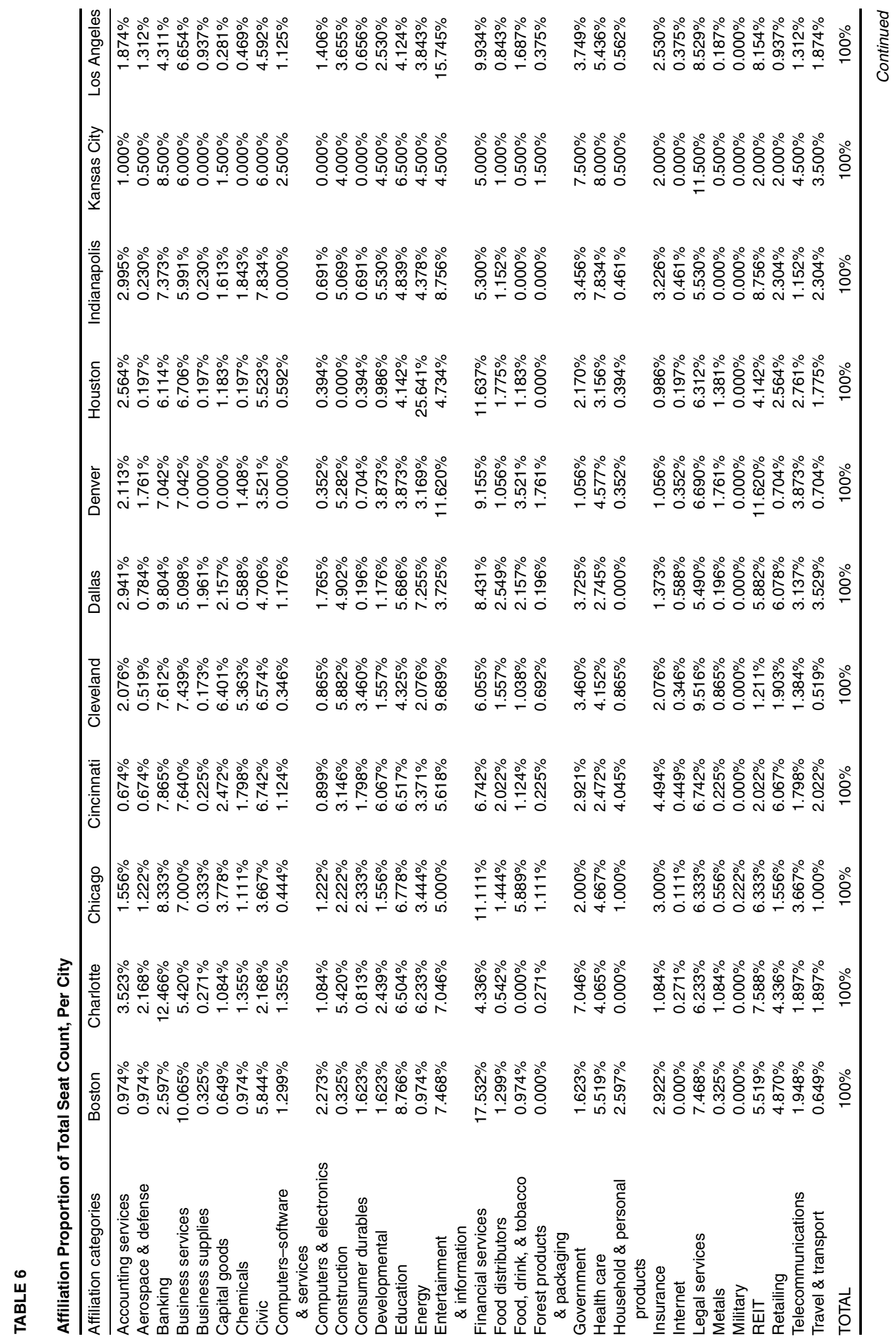




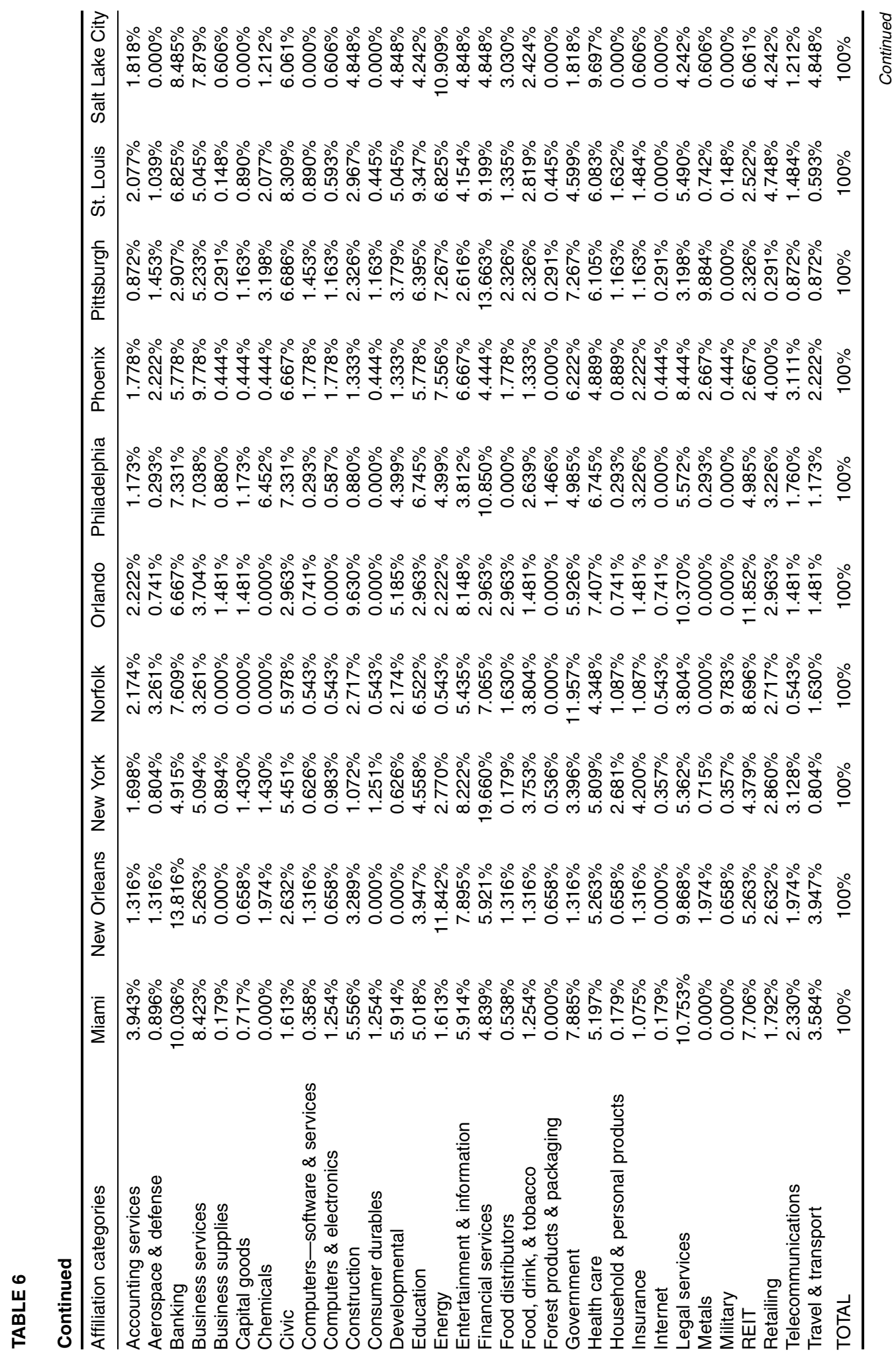




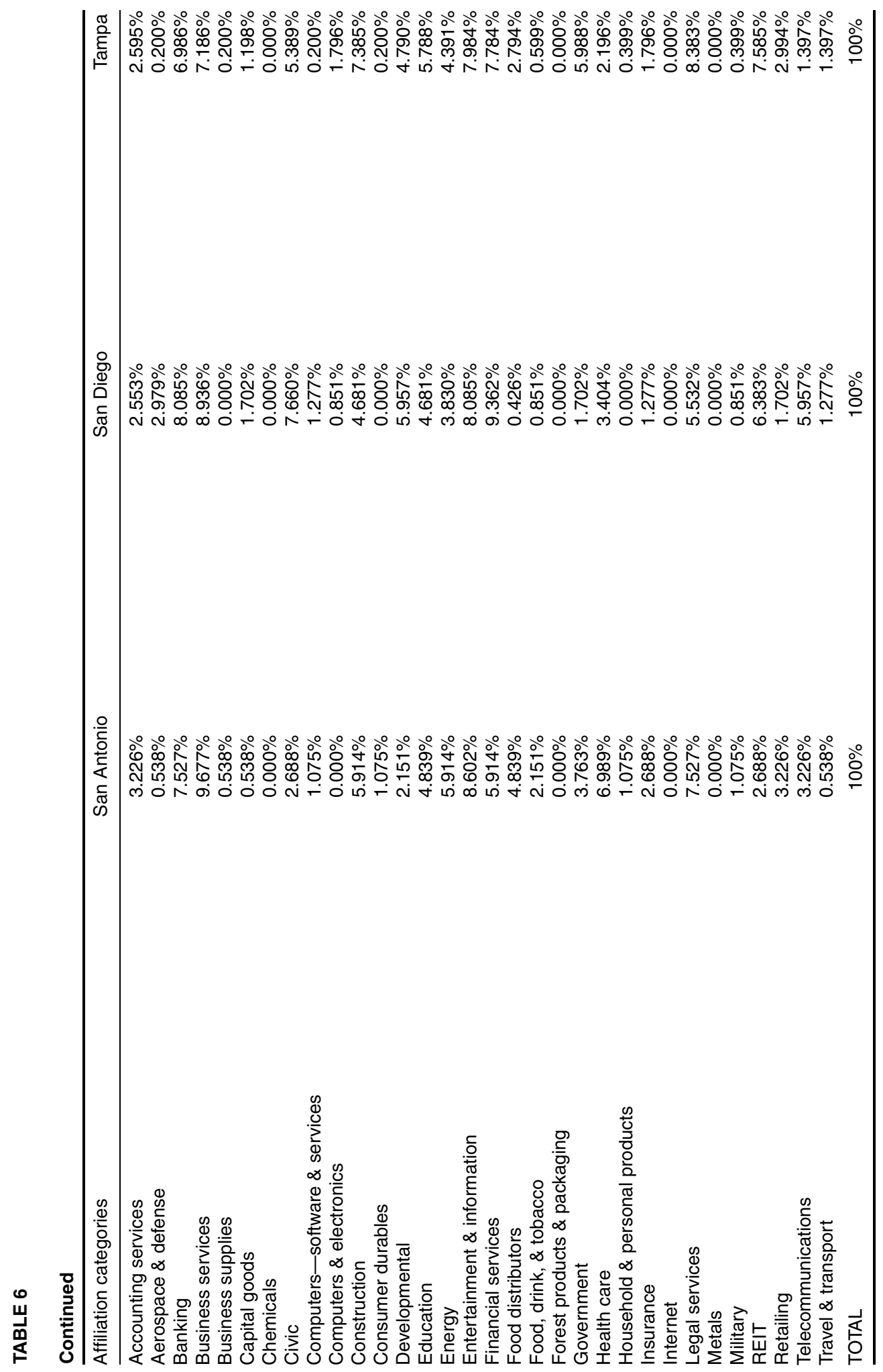




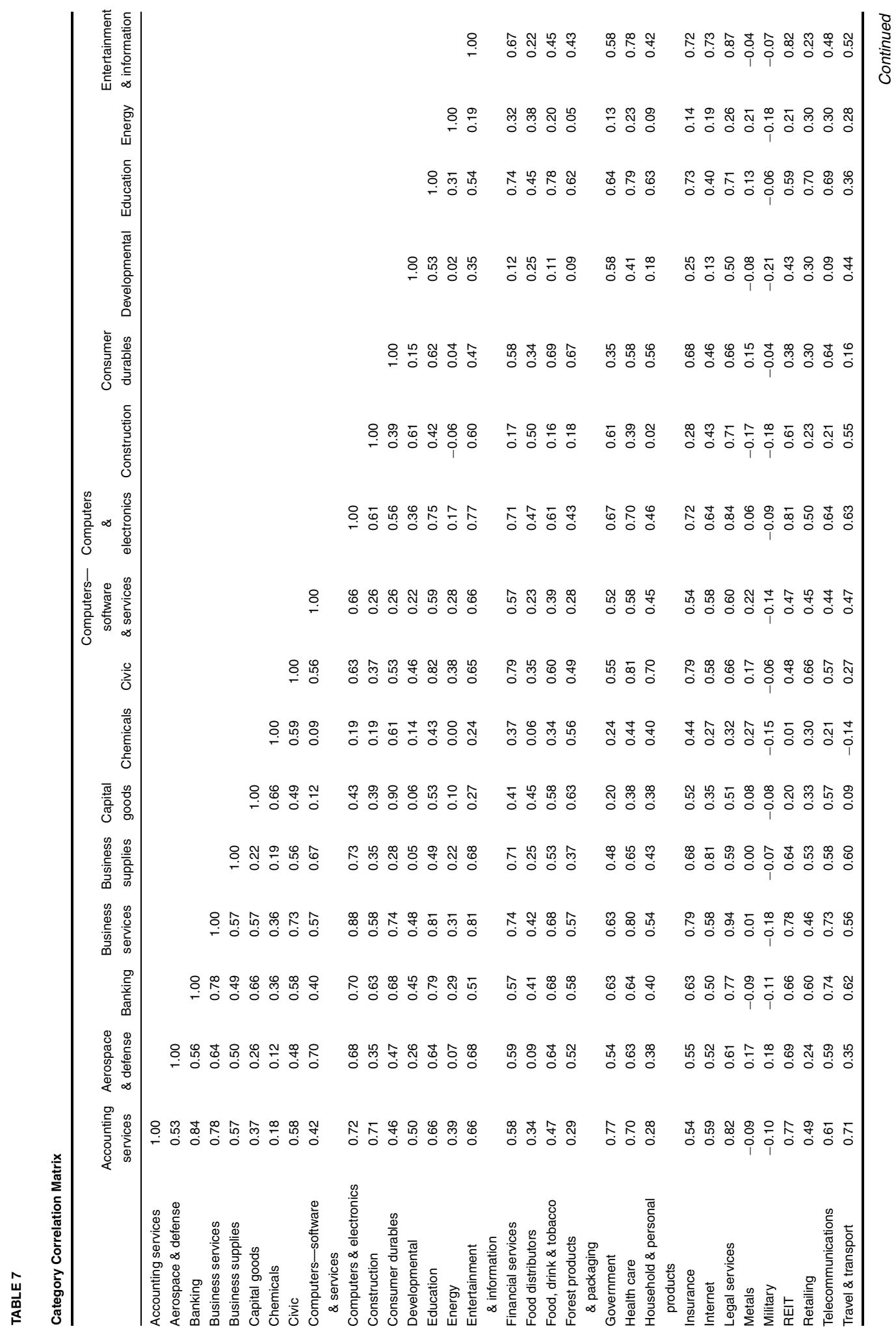




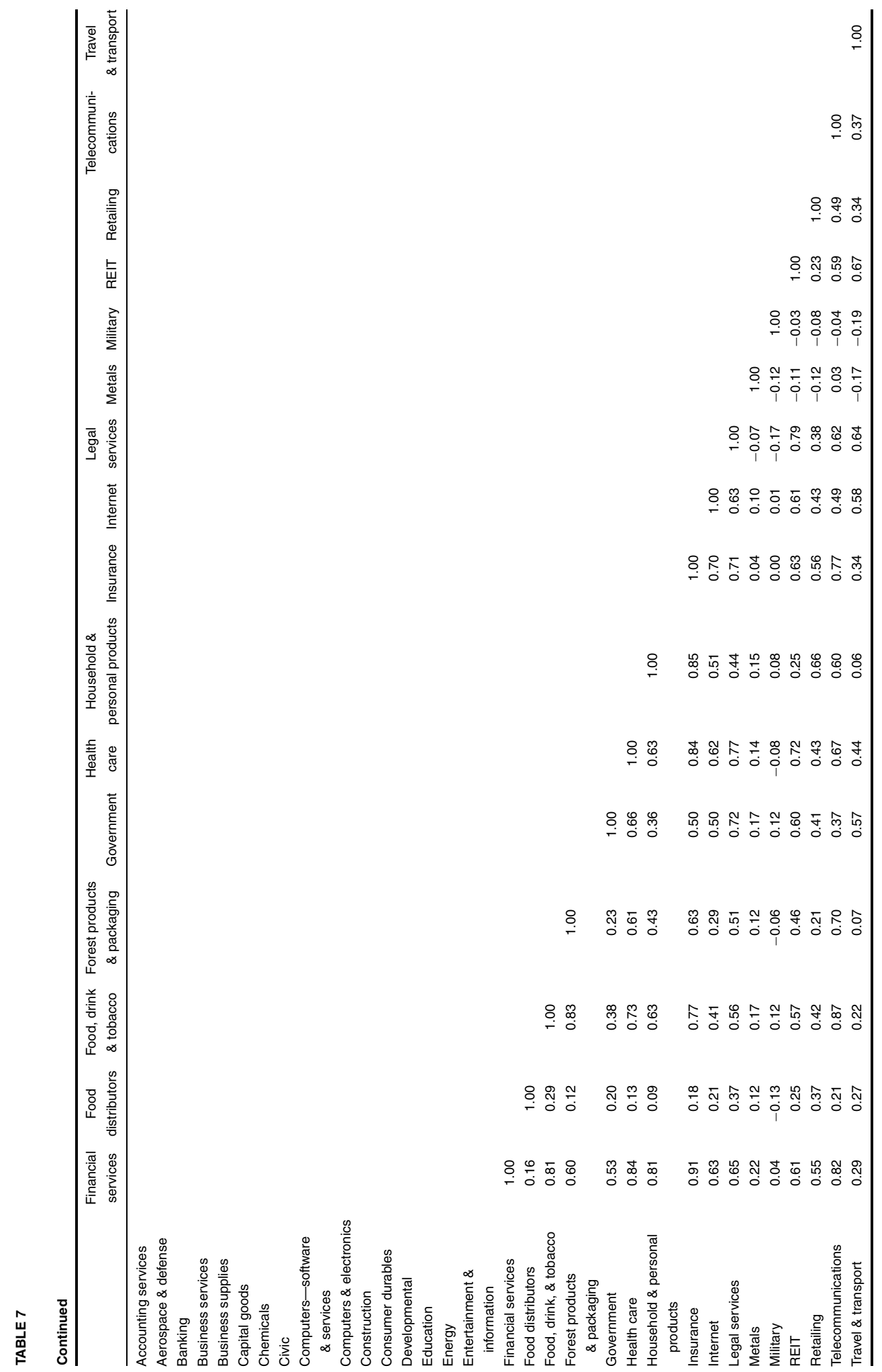


TABLE 8

Factor Loadings (Varimax Rotation)

\begin{tabular}{|c|c|c|c|c|c|}
\hline \multirow[b]{2}{*}{ Categories of director affiliations } & \multicolumn{5}{|c|}{ Component } \\
\hline & 1 & 2 & 3 & 4 & 5 \\
\hline Accounting services & 0.418 & 0.834 & 0.101 & 0.239 & 0.001 \\
\hline Aerospace \& defense & 0.730 & 0.403 & 0.206 & -0.281 & -0.135 \\
\hline Banking & 0.305 & 0.687 & 0.547 & 0.264 & -0.048 \\
\hline Business services & 0.556 & 0.631 & 0.475 & 0.181 & 0.007 \\
\hline Business supplies & 0.845 & 0.344 & 0.040 & 0.166 & -0.140 \\
\hline Capital goods & -0.095 & 0.089 & 0.954 & 0.145 & 0.004 \\
\hline Chemicals & -0.010 & -0.211 & 0.783 & -0.052 & 0.487 \\
\hline Civic & 0.658 & 0.143 & 0.498 & 0.248 & 0.415 \\
\hline Computers-software \& services & 0.856 & 0.267 & -0.112 & 0.165 & 0.117 \\
\hline Computers \& electronics & 0.645 & 0.675 & 0.232 & 0.151 & -0.030 \\
\hline Construction & -0.026 & 0.967 & 0.057 & 0.075 & 0.146 \\
\hline Consumer durables & 0.172 & 0.168 & 0.940 & -0.027 & 0.033 \\
\hline Developmental & 0.009 & 0.780 & -0.068 & 0.090 & 0.506 \\
\hline Education & 0.543 & 0.351 & 0.589 & 0.252 & 0.223 \\
\hline Energy & 0.226 & -0.095 & -0.186 & 0.838 & -0.106 \\
\hline Entertainment \& information & 0.698 & 0.631 & 0.115 & -0.061 & 0.005 \\
\hline Financial services & 0.864 & -0.009 & 0.479 & 0.061 & 0.004 \\
\hline Food distributors & -0.288 & 0.408 & 0.144 & 0.719 & -0.048 \\
\hline Food, drink, \& tobacco & 0.567 & -0.011 & 0.760 & -0.005 & -0.202 \\
\hline Forest products \& packaging & 0.352 & 0.000 & 0.874 & -0.122 & -0.062 \\
\hline Government & 0.471 & 0.748 & -0.092 & -0.078 & 0.298 \\
\hline Health care & 0.787 & 0.356 & 0.424 & -0.026 & 0.189 \\
\hline Household \& personal products & 0.682 & -0.262 & 0.550 & 0.004 & 0.204 \\
\hline Insurance & 0.772 & 0.148 & 0.584 & -0.004 & 0.057 \\
\hline Internet & 0.774 & 0.396 & 0.064 & 0.037 & -0.054 \\
\hline Legal services & 0.506 & 0.773 & 0.314 & 0.111 & 0.079 \\
\hline Metals & 0.003 & -0.662 & -0.012 & 0.016 & 0.331 \\
\hline Military & -0.046 & -0.346 & -0.149 & -0.611 & -0.419 \\
\hline REIT & 0.585 & 0.765 & 0.068 & -0.012 & -0.160 \\
\hline Retailing & 0.490 & 0.108 & 0.290 & 0.516 & 0.199 \\
\hline Telecommunications & 0.650 & 0.151 & 0.648 & 0.158 & -0.259 \\
\hline Travel \& transport & 0.377 & 0.813 & -0.263 & 0.255 & -0.107 \\
\hline Eigenvalue & 9.459 & 8.085 & 6.828 & 2.471 & 1.461 \\
\hline Percentage of Variance & 29.560 & 25.266 & 21.338 & 7.721 & 4.575 \\
\hline Cumulative (\%) of Variance & 29.560 & 54.826 & 76.164 & 83.885 & 88.461 \\
\hline
\end{tabular}

(1) manage and restrict growth, or (2) emphasize historical preservation, quality of design, culture, and the arts (Kerstein, 1993; Sbragia, 1990; Stone, 1987, 1993; Ward, 1996).

Table 9 lists directorship affiliation categories by highest factor score. Contained in the first factor is the category of 'civic,' which is the only category that is widely identified in regime theory as meaningful in terms of determining the nature of "progressive" regime types (Dowding, 2001; Kerstein, 1993; Kilburn, 2004; Orr, 1992; Sbragia, 1990). It is the one identifiable category within the factor that suggests the factor may be a list of markers for the mix of business elite affiliations that might indicate a political orientation of a more progressive character. Additionally, the factor contains an eclectic mix of directorship affiliations representing high technology (aerospace \& defense, health care), multimedia services (computer software \& services, entertainment $\&$ information, internet, telecommunications), and traditional services (business supplies, household $\&$ personal products, insurance, and financial services). Interestingly, this list of directorship 
TABLE 9

Three Major Factors and Their Associated Categories (Varimax Rotation)

\begin{tabular}{lll}
$\begin{array}{l}\text { Factor } 1 \\
\text { (Progressive) }\end{array}$ & \multicolumn{1}{c}{$\begin{array}{c}\text { Factor } 2 \\
\text { (Developmental) }\end{array}$} & \multicolumn{1}{c}{$\begin{array}{c}\text { Factor } 3 \\
\text { (Caretaker) }\end{array}$} \\
\hline $\begin{array}{l}\text { Aerospace \& defense } \\
\text { Business supplies }\end{array}$ & $\begin{array}{l}\text { Accounting services } \\
\text { Banking }\end{array}$ & $\begin{array}{l}\text { Capital goods } \\
\text { Chemicals }\end{array}$ \\
Civic & Business services & Consumer durables \\
Computers-software \& services & Computers \& electronics & Education \\
Entertainment \& information & Construction & Food, drink \& tobacco \\
Financial services & Developmental & Forest products \& packaging \\
Health care & Government & \\
Household \& personal products & Legal services & \\
Insurance & REIT & \\
Internet & Travel \& transport & \\
Telecommunications & & \\
\hline
\end{tabular}

affiliations in the economic sector appears to closely resemble Richard Florida's (2002, p. 47) list of "core industries of the creative class." Florida refers to the workforce of these industries as the "creative class" in order to express "the sense that its members are the fountainhead of innovative energy and cultural dynamism in modern urban society" (Scott, 2006, p. 4). Florida (2002, 2003) suggests that cities should embark on economic development strategies centered on tolerance of gay and lesbian lifestyles, promotion of the arts and cultural activities, and creating a vibrant nightlife in order to establish "creativity-inducing" environments coveted by the largely young and affluent workforce. Progressiveness in this context more closely resembles the middle-class progressive regime or the middle-class arts-and-culture progressive regime type that focuses on historical preservation, quality of urban design, tourism, or environmental quality rather than a low-income, opportunity-expanding progressive regime prototype (Gladstone \& Fainstein, 2001; Stone, 1993). Factor one is labeled here as a middle-class arts-and-culture progressive regime factor to account for both the category of "civic" and also for the mix of categories akin to Florida's "creative" industries.

The second factor contains directorship affiliations that one would expect to find in a city with a developmental regime characterization. Grouped here are public-private partnerships (categorized as "developmental"), real estate firms, travel and transportation firms, construction, and legal services. The literature regarding developmental regimes would indicate that where there is a high representation of public-private partnerships, one would also expect relatively high representations of construction and real estate since developmental organizations are often public-private partnerships, business roundtables, or local authorities that are geared towards altering the land use of urban centers, which would entail the financing and construction of new buildings or landmarks. The association between government entities and legal services is also a logical one. Additionally, one would anticipate a common high score for the categories of "government" and "developmental' given the nature of developmental agencies as public-private partnerships between public officials and business elites. This factor, then, can be thought of as a developmental factor.

Manufacturing-based affiliations cluster together in factor three and represent a stark contrast to factors one and two. Harvey (1989) suggests that the traditional function of municipal governments prior to the entrepreneurial turn of the early 1980s was "managerial" in nature and focused primarily on the provision of municipal services. Urban governments were forced to become more entrepreneurial as a result of structural changes in their economies: manufacturing largely moved 
south or overseas and federal expenditures on cities were substantially reduced. The caretaker type of regime reflects a managerial style of governance through its focus on municipal service provision and the maintenance of a social and political status quo. It is hypothesized that one will find caretaker regimes in cities where manufacturing continues to dominate their economies. Factor three is therefore labeled as a caretaker factor.

The characterizations of the three factors allow for the construction of prototype profiles representing the business resources comprising three general regime typologies of developmental, caretaker, and progressive. The city profiles are correlated through scatter plots with each of the three prototypes and the findings compared against existing case studies.

\section{RESULTS}

Fifteen of the twenty-four cities in this study had been previously studied and their regimes characterized (Table 3). For the remaining nine cities, expectations of regime types, or rather, expectations of high regime prototype correlations are provided along with justification for their expectations (Table 4). Correlations of ten of the fifteen case-studied cities match the regime types ascribed by their case studies (Table 10). Three of the remaining five (New York, Chicago, and Houston) match with qualification; that is, they could reasonably have been expected to correlate with the prototype that they did. This study takes issue with their regime characterizations by previous case studies.

\section{TABLE 10}

City Correlations with Regime Prototypes

\begin{tabular}{lcccccc}
\hline & \multicolumn{3}{c}{ Regime prototypes } & & \\
City & Caretaker & Developmental & Progressive & Case-study or expected Regime type & Match? \\
\cline { 2 - 4 } Boston & 0.665 & 0.750 & $\mathbf{0 . 7 8 3}$ & Progressive & Yes \\
Charlotte & 0.801 & $\mathbf{0 . 8 3 8}$ & 0.763 & Developmental & Yes \\
Chicago & 0.845 & 0.787 & $\mathbf{0 . 8 5 7}$ & Developmental & No \\
Cincinnati & 0.766 & $\mathbf{0 . 7 8 9}$ & 0.775 & Developmental & Yes \\
Cleveland & $\mathbf{0 . 7 7 0}$ & 0.691 & 0.747 & Developmental & No \\
Dallas & 0.821 & $\mathbf{0 . 8 5 4}$ & 0.842 & Developmental & Yes \\
Denver & 0.736 & 0.819 & $\mathbf{0 . 8 2 9}$ & Progressive & Yes \\
Houston & $\mathbf{0 . 7 0 1}$ & 0.614 & 0.658 & Developmental & No \\
Indianapolis & 0.786 & $\mathbf{0 . 8 9 3}$ & 0.835 & Developmental & Yes \\
Kansas City & 0.780 & $\mathbf{0 . 8 2 0}$ & 0.732 & Developmental & Yes \\
Los Angeles* & 0.741 & $\mathbf{0 . 8 3 5}$ & 0.832 & Progressive & No \\
Miami & 0.719 & $\mathbf{0 . 8 2 5}$ & 0.704 & Progressive & No \\
New Orleans & $\mathbf{0 . 8 7 7}$ & 0.766 & 0.813 & Caretaker & Yes \\
New York & 0.665 & 0.716 & $\mathbf{0 . 7 6 4}$ & Developmental & No \\
Norfolk & 0.419 & $\mathbf{0 . 5 9 6}$ & 0.481 & Caretaker & No \\
Orlando & 0.575 & $\mathbf{0 . 7 5 1}$ & 0.617 & Progressive & No \\
Philadelphia* & 0.817 & $\mathbf{0 . 8 2 9}$ & 0.824 & Developmental & Yes \\
Phoenix & $\mathbf{0 . 8 4 3}$ & 0.819 & 0.831 & Progressive & No \\
Pittsburgh & 0.558 & $\mathbf{0 . 5 7 3}$ & 0.563 & Developmental & Yes \\
Saint Louis & 0.841 & $\mathbf{0 . 8 5 8}$ & 0.819 & Developmental & Yes \\
Salt Lake City* & $\mathbf{0 . 8 0 7}$ & 0.802 & 0.755 & Caretaker & Yes \\
San Antonio & $\mathbf{0 . 8 5 8}$ & 0.846 & 0.815 & Caretaker & Yes \\
San Diego* & 0.788 & $\mathbf{0 . 8 8 3}$ & $\mathbf{0 . 8 8 3}$ & Caretaker & No \\
Tampa & 0.788 & $\mathbf{0 . 9 3 8}$ & 0.849 & Progressive & No \\
\hline
\end{tabular}

Notes: Bold represents highest correlations. All data, city profiles, and the like, are available upon request to the author. *Denotes strong correlations with more than one regime prototype. 
In the cases of Chicago and New York, previous studies have noted the very active roles of downtown business elites in reshaping their respective downtowns. Bennett et al. (1988), for example, presents the long history of Chicago's downtown business elite's role in planning and shaping the city's North Loop from the 1940s through the early 1980s. They conclude by illustrating the dismantling of Chicago's powerful machine-politics of the 1950s and the subsequent fragmentation of the elite's hold on downtown development strategies by the late 1970 s and early 1980s. Bennett et al. argue that a city once dominated by a powerful ward-based political "machine" headed by long-time mayor Richard Daley was forced to change as a growing array of civil rights, neighborhood, social, and political activist groups increasingly challenged the machine's hegemony. By 1985, the year with which the study concludes, Chicago's politics are seen to be fragmented and pluralistic. This study, however, is a snapshot of Chicago's directorship affiliations in 2003 and suggests that Chicago's politics may have continued the trend and more fully transitioned towards a progressive or pluralist orientation since the 1980s.

Further, what Bennett et al. (1988, Chicago) and Whitt (1987, 1988, New York) cite as evidence of a developmental regime at work in both cities were interpreted here as evidence of progressive regimes. For example, Bennett et al. discuss efforts of the Landmarks Preservation Council to restore architecturally historic buildings in Chicago's CBD, and efforts by the Chicago Theater and the Chicago Performing Arts Center to maintain their presence in the CBD. These examples are presented as evidence of a developmental regime in Chicago because both had gained substantial support from the city's downtown business elite. Whitt (1987), meanwhile, points to New York City's performing arts groups' place in the city's urban growth machine. In the case of both cities, such organizations can be deemed active "civic" groups geared towards enhancing quality of life - a use value function of space rather than an exchange value function (Cox, 1995; Logan \& Molotch, 1987). Consequently, civic group participation in regime coalitions is interpreted here as indicative of a progressive-type regime. Therefore, the correlations of Chicago and New York with the middle-class arts-and-culture progressive regime prototype rather than the developmental prototype are not wholly inconsistent with previous studies-the difference is one of operationalizing regime characterizations.

In the case of Houston, previous studies have indicated that the city's business elites have lobbied against property taxes and for laissez faire policies on the part of local government. Normally, laissez faire policies are characteristics associated with a caretaker-type regime (Harvey, 1989; Stone, 1989, p. 188). However, for Feagin (1985, 1988) and Kirby and Lynch (1987), the failure of Houston's municipal government to intervene in the growth process, or rather, efforts by regime partners to actively block attempts at growth management even as rapid growth led to mounting social costs, is evidence of a pro-growth developmental-type regime. This study finds that Houston's corporate, civic, and developmental sectors have the makeup of a caretaker-type regime - and the evidence of laissez faire policies in Houston largely supports this, in contrast to Feagin's, and Kirby and Lynch's, alternative take on Houston's politics. However, rather than the difference being one of operationalizing regime characterizations, it is most likely that this study's finding of Houston correlating more closely with the caretaker regime prototype is a victim of generalization that a comparative analysis demands. The nuances of Houston politics as documented by Feagin $(1985,1988)$ are lost in a comparative study like this and represent the weakness of scope versus depth inherent in comparative analyses (Kantor \& Savitch, 2005, p. 137).

Each of the Florida cities of Tampa, Orlando, and Miami match the developmental prototype more closely than the expected progressive model. Kerstein (1993) and Kirby \& Lynch (1987) provide the main justification for expecting these cities to correlate with the progressive prototype. In fast-growing cities such as Tampa and Houston, citizens were mobilized to form formidable growth-regulating coalitions that the authors labeled "progressive." However, the pro-"smart 
growth" civic groups and community organizations identified by Kerstein (Tampa) and Kirby and Lynch (Houston) were not found to be prominently represented on those cities' boards of directors in 2003. The relative absence of such organizations thus tilts these cities towards the developmental regime prototype rather than the expected progressive regime prototype.

For the cities of Norfolk and San Diego, it was assumed that with the presence of unusually large military bases, these cities would reflect caretaker-type characteristics. The category of military is irrelevant, however, in terms of influencing a city's political orientation. All of its factor scores were negative, and its largest factor score falls outside of the three main factors. The particular mixes of director affiliations for Norfolk and San Diego instead places them tentatively within the developmental regime prototype along with other Sun Belt cities like Tampa, Orlando, Miami, and Charlotte. San Diego interestingly correlates equally with both the progressive and developmental prototypes.

The city of Cleveland is an interesting case. It correlated more closely with the caretaker regime prototype, but its case-study suggests that Cleveland has a developmental political orientation by virtue of the city's active reshaping of urban land use by emphasizing new stadiums for the city's two major professional sports franchises (Indians and Browns), the building of the Rock 'n Roll Hall of Fame, and other activities (Austrian \& Rosentraub, 2002). These are indeed indicators of a developmental orientation and suggest that the Cleveland case, like that of Houston, is a casualty of scope versus depth.

Six of the nine cities that did not correlate as expected (including Norfolk, San Diego, Miami, and Orlando-all discussed above) were not previously case-studied. It is quite reasonable that the disconnection with expected prototypes is a result of underdeveloped assumptions. Clearly more success was gained by relying on previous case studies. While this study suggests greater methodological diversity within regime studies, particularly concerning comparative analyses, this study demonstrates that the case-study method should remain a vital methodological approach within regime theory.

\section{CONCLUSION}

Regimes are not static but rather are dynamic and reflect forces of change through time (Stone, 1989, p. 9). The composition and policy agendas of urban political coalitions change in response to broader economic and social forces. We can imagine that the composition of business elites-central to all regime coalitions-changes through time as a result of broader economic restructuring (DiGaetano \& Klemanski, 1989, pp. 122-125; Fainstein et al., 1983). Corporate mergers and acquisitions, bankruptcies, and the rise of new economic sectors and the demise of others are manifest in the changing compositions of business elites and the resources that they command. There is also a spatial component: on the one hand, as new economic sectors rise, so do the places where they are located. On the other hand, as other economic sectors falter, so do the places where they are located.

These changing economic fortunes are manifest in urban politics as well. The rise of new economic sectors like computer hardware and software, multimedia, telecommunications technologies, or even global finance, mean that cities where these industries are based often face problems associated with rapid population growth. These include the funding of infrastructural development for commercial and residential uses, upward pressure on wages and housing costs, rising social inequality, the lack of affordable housing, and environmental degradation. Coalitions that develop in these cities tend to have stable fiscal bases since their economic sectors with whom they partner are generally strong and their populations are stable or growing. Kilburn (2004) suggests that a stronger fiscal base increases the likelihood of a city developing a progressive regime, and Florida (2002, pp. 246-247) suggests that these "new" economic sectors are driven by a 
"creative" workforce that demands diversity and a vibrant cultural life to stoke the creativity their jobs demand.

Meanwhile, many older industrial cities struggle with declining economic sectors, decreasing population, dwindling tax revenues, aging infrastructure, increased demand for social and municipal services concomitant with increased concentrations of poverty, and other serious problems (Fainstein et al., 1983). These cities must partner with local business elites in order to forge policies aimed at slowing the decline or attempting to (re)position the city so that it benefits in some way from continuing economic restructuring by attracting inward investments (Cox, 1995; Harvey, 1989). In both cases, business elites and the resources they command are at the center of urban coalitions, but the composition of their corporate communities and the resources they represent vary.

Resources are a key ingredient for the ability of regimes to emerge and sustain a policy agenda over relatively long and stable periods of time (Stone, 1989). Stone writes, "the term resources includes not just material matters but also such things as skills, expertise, organizational connections, informal contacts, and level and scope of contributing effort by participants" (Stone, 2005, p. 329). Interlocking directorates largely embody the range of skills, expertise, organizational connections, and informal contacts available to regime participants. Additionally, the kinds of skills, expertise and organizational connections attributed to business elites are diverse and contingent upon the particular mix of corporations based in cities and the historical trajectories of local economies.

Further, informal cooperation among local business, political and social leaders is vital to the capacity of regimes to govern (Stone, 1989, p. 3). "But these [...] arrangements are not neutral; they bias what can and cannot be done with the capacity to govern" (Stone, 1989, p. 219). The particular composition of local business communities embodied through interlocking directorates may predispose the political orientation of participatory business elites towards some urban policies over others. Various industries contain different corporate structures that are functional to the industries of which they are a part (McNee, 1958; Roberts \& Murray, 2002; Stafford, 1979; Storper \& Walker, 1989; Van den Berg, Braun, \& Otgaar, 2004). That elites command different sets of expertise and resources according to the industries and organizations to which they are affiliated may have some bearing on the kinds of viewpoints they advance and the types of urban policies that they would be inclined to support, therefore biasing what can or cannot be done with the capacity to govern.

\section{ENDNOTE}

1 This list of works considering the impact of social cohesion on the market behavior of firms is by no means exhaustive.

\section{REFERENCES}

Anderson, C. A., \& Anthony, R. N. (1986). The new corporate directors: Insights for board members and executives. New York: John Wiley \& Sons.

Andranovich, G., Burbank, M. J., \& Heying, C. H. (2001). Olympic cities: Lessons learned from mega-events politics. Journal of Urban Affairs, 23(2), 113-131.

Austin, J., \& McCaffrey, A. (2002). Business leadership coalitions and public-private partnerships in American cities: A business perspective on regime theory. Journal of Urban Affairs, 24(1), 35-54.

Austrian, Z., \& Rosentraub, M. S. (2002). Cities, sports, and economic change: A retrospective assessment. Journal of Urban Affairs, 24(5), 549-563. 
Barnes, R. C., \& Ritter, E. R. (2001). Networks of corporate interlocking: 1962-1995. Critical Sociology, 27(2), 192-220.

Bennett, L., McCourt, K., Nyden, P. W., \& Squires, G. D. (1988). Chicago's North Loop redevelopment project: A growth machine on hold. In S. Cummings (Ed.), Business elites and urban development (pp. 183-199). Albany: State University of New York Press.

Boyle, M., \& Silver, I. (2005). Poverty, partnerships, and privilege: Elite institutions and community empowerment. City and Community, 4(3), 233-253.

Brayshay, M., Clearly, M., \& Selwood, J. (2005). Interlocking directorships and trans-national linkages within the British Empire, 1900-1930. Area, 37(2), 209-222.

Brown, C., \& Paul, D. M. (2000). The campaign by Cincinnati business interests for strong mayor and sports stadia. The Social Science Journal, 37(2), 161-176.

Burris, V. (1991). Director interlocks and the political behavior of corporations and corporate elites. Social Science Quarterly, 72(3), 537-551.

Burt, R. S. (1980). Cooptive corporate actor networks: A reconsideration of interlocking directorates involving American manufacturing. Administrative Science Quarterly, 25(4), 557-582.

Carminatti-Marchand, G., \& Paquerot, M. (2001). The elite and their boards of directors. ESCEM-CRESS, Research compilation book of the ESCEM School of Business and Management No. 2. http://ssrn.com/ abstract $=261948$.

Cox, K. R. (1995). Globalization, competition and the politics of local economic development. Urban Studies, 32(2), 213-224.

Davies, J. S. (2004). Can't hedgehogs be foxes too? Reply to Clarence N. Stone. Journal of Urban Affairs, 26(1), 27-33.

Davis, G. F., \& Mizruchi, M. S. (1999). The money center cannot hold: Commercial banks in the U.S. system of corporate governance. Administrative Science Quarterly, 44(2), 215-239.

Demb, A., \& Neubauer, F. (2002). The corporate board: Confronting the paradoxes. Oxford: Oxford University Press.

DiGaetano, A., \& Klemanski, J. S. (1989). Power and city governance: Comparative perspectives on urban development. Minneapolis: University of Minnesota Press.

DiMaggio, P. J., \& Anheier, H. K. (1990). The sociology of nonprofit organizations and sectors. Annual Review of Sociology, 16, 137-159.

Domhoff, G. W. (1967). Who rules America? Englewood Cliffs, NJ: Prentice-Hall.

Domhoff, G. W. (1970). The higher circles: The governing class in America. New York: Random House.

Domhoff, G. W. (Ed.). (1980). Power structure research. New York: Sage.

Domhoff, G. W. (2006). The limitations of regime theory. City and Community, 5(1), 47-51.

Dowding, K. (2001). Explaining urban regimes. International Journal of Urban and Regional Research, 25(1), $7-19$.

Elkin, S. (1987). City and regime in the American republic. Chicago: University of Chicago Press.

Everard, A., \& Henry, R. (2002). A social network analysis of interlocked directorates in electronic commerce firms. Electronic Commerce Research and Applications, 1, 225-234.

Fainstein, S. S., Fainstein, N. I., Hill, R. C., Judd, D., \& Smith, M. P. (1983). Restructuring the city: The political economy of urban redevelopment. New York: Longman.

Feagin, J. R. (1985). The global context of metropolitan growth: Houston and the oil industry. American Journal of Sociology, 90, 1204-1230.

Feagin, J. R. (1988). Tallying the social costs of urban growth under capitalism: The case of Houston. In S. Cummings (Ed.), Business elites and urban development (pp. 205-234). Albany: State University of New York Press.

Ferman, B. (1996). Challenging the growth machine: Neighborhood politics in Chicago and Pittsburgh. Lawrence: University Press of Kansas.

Finch, E. M., \& White, L. J. (2005). Why do CEOs reciprocally sit on each other's boards? Journal of Corporate Finance, 11, 175-195.

Florida, R. (2002). The rise of the creative class and how it's transforming work, leisure, community, and everyday life. New York: Basic Books.

Florida, R. (2003). Cities and the creative class. City and Community, 2(1), 3-19. 
Galaskiewicz, J. (1985). Interorganizational relations. Annual Review of Sociology, 11, 281-304.

Galaskiewicz, J., \& Bielefeld, W. (1998). Nonprofitorganizations in an age of uncertainty: A study of organizational change. New York: Aldine de Gruyter.

Geletkanycz, M. A., \& Hambrick, D. C. (1997). The external ties of top executives: Implications for strategic choice and performance. Administrative Science Quarterly, 42(4), 654-681.

Gissendanner, S. (2003). Methodology problems in urban governance studies. Environment and Planning C, 21(5), 663-685.

Gladstone, D. L., \& Fainstein, S. S. (2001). Tourism in US global cities: A comparison of New York and Los Angeles. Journal of Urban Affairs, 23(1), 23-40.

Glassberg, A. D. (1991). St. Louis: Racial transformation and economic development. In H. V. Savitch \& J. C. Thomas (Eds.), Big city politics in transition (pp. 86-96). Newbury Park, CA: Sage.

Green, M. B., \& Semple, R. (1981). The corporate interlocking directorate as an urban spatial information network. Urban Geography, 2, 148-160.

Harding, A. (2000). Regime formation in Manchester and Edinburgh. In G. Stoker (Ed.), The new politics of British local governance (pp. 54-71). New York: St. Martin's Press.

Harvey, D. (1989). From managerialism to entrepreneurialism: The transformation in urban governance in late capitalism. Geografiska Annaler, 71(B), 3-17.

Harvey, D. (2005). A brief history of neoliberalism. Oxford: Oxford University Press.

Haunschild, P. R. (1993). Interorganizational imitation: The impact of interlocks on corporate acquisition activity. Administrative Science Quarterly, 38(4), 564-592.

Hunter, F. (1953). Community power structure: A study of decision makers. Chapel Hill: The University of North Carolina Press.

Imbroscio, D. L. (1998). The necessity of urban regime change: A reply to Clarence N. Stone. Journal of Urban Affairs, 20(3), 261-268.

Imbroscio, D. L. (2003). Overcoming the neglect of economics in urban regime theory. Journal of Urban Affairs, 25(3), 271-284.

Imbroscio, D. L. (2004). The imperative of economics in urban political analysis: A reply to Clarence N. Stone. Journal of Urban Affairs, 26(1), 21-26.

Jo, H. J. (2002). Regional restructuring and urban regimes: A comparison of the Pittsburgh and Detroit metropoli$\tan$ areas. Ann Arbor, MI: Office for the Study of Automotive Transportation, University of Michigan Transportation Research Institute (UMTRI 2002-20).

Kachigan, S. K. (1991). Multivariate statistical analysis: A conceptual introduction. New York: Radius Press.

Kantor, P., \& Savitch, H. V. (2005). How to study comparative urban development politics: A research note. International Journal of Urban and Regional Research, 29(1), 135-151.

Kerstein, R. (1993). Suburban growth politics in Hillsborough County: Growth management and political regimes. Social Science Quarterly, 74(3), 614-630.

Kilburn, H. W. (2004). Explaining U.S. urban regimes: A qualitative comparative analysis. Urban Affairs Review, 39(5), 633-651.

Kirby, A., \& Lynch, A. K. (1987). A ghost in the growth machine: The aftermath of rapid population growth in Houston. Urban Studies, 24, 587-596.

Lang, J. R., \& Lockhart, D. E. (1990). Increased environmental uncertainty and changes in board linkages patterns. The Academy of Management Journal, 33(1), 106-128.

Logan, J. R., \& Molotch, H. L. (1987). Urban fortunes: The political economy of place. Berkeley: University of California Press.

Loderer, C., \& Peyer, U. (2002). Board overlap, seat accumulation, and share prices. European Financial Management, 8(2), 165-192.

Lorsch, J. W., \& MacIver, E. (1989). Pawns or potentates: The reality of America's corporate boards. Boston: Harvard Business School Press.

Lyson, T. A., \& Raymer, A. L. (2000). Stalking the wily multinational: Power and control in the US food system. Agriculture and Human Values, 17, 199-208.

Mace, M. E. (1971). Directors: Myth and reality. Boston: Division of Research, Harvard Business School.

Martin, D. G. (2004). Nonprofit foundations and grassroots organizing: Reshaping urban governance. The Professional Geographer, 56(3), 394-405. 
McNee, R. (1958). Functional geography of the firm, with an illustrative case study from the petroleum industry. Economic Geography, 34(4), 321-337.

Mier, R., Moe, K. J., \& Sherr, I. (1986). Strategic planning and the pursuit of reform, economic development, and equity. Journal of the American Planning Association, 52(3), 299-309.

Mills, C. W. (1956). The power elite. New York: Oxford University Press.

Mintz, B., \& Schwartz, M. (1983). Financial interest groups and interlocking directorates. Social Science History, 7(2), 183-204.

Mintz, B., \& Schwartz, M. (1985). The power structure of American business. Chicago: University of Chicago Press.

Mizruchi, M. S. (1992). The structure of corporate political action: Interfirm relations and their consequences. Cambridge, MA: Harvard University Press.

Mizruchi, M. S. (1996). What do interlocks do? An analysis, critique, and assessment of research on interlocking directorates. Annual Review of Sociology, 22, 271-298.

Mizruchi, M. S., \& Stearns, L. B. (1988). A longitudinal study of the formation of interlocking directorates. Administrative Science Quarterly, 33(2), 194-210.

Moore, G., Sobieraj, S., Whitt, J. A., Mayorova, O., \& Beaulieu, D. (2002). Elite interlocks in three U.S. sectors: Nonprofit, corporate, and government. Social Science Quarterly, 83(3), 726-744.

Mossberger, K., \& Stoker, G. (2001). The evolution of urban regime theory: The challenge of conceptualization. Urban Affairs Review, 36(6), 810-835.

O’Hagan, S. B., \& Green, M. B. (2002). Interlocking directorates: An example of tacit knowledge transfer. Urban Geography, 23(2), 154-179.

O’Hagan, S. B., \& Green, M. B. (2004). Corporate knowledge transfer via interlocking directorates: A network analysis approach. Geoforum, 35, 127-139.

Orr, M. (1992). Urban regimes and human capital policies: A study of Baltimore. Journal of Urban Affairs, 14(2), 173-187.

Parker, R. E., \& Feagin, J. R. (1990). A 'better business climate' in Houston. In D. Judd \& M. Parkinson (Eds.), Leadership and urban regeneration (pp. 216-238). Newbury Park, CA: Sage.

Pfeffer, J. (1972a). Merger as a response to organizational interdependence. Administrative Science Quarterly, 17(3), 382-394.

Peffer, J. (1972b). Size and composition of corporate boards of directors: The organization and its environment. Administrative Science Quarterly, 17(2), 218-228.

Pfeffer, J. (1987). A resource dependence perspective on intercorporate relations. In M. S. Mizruchi \& M. Schwartz (Eds.), Intercorporate relations: The structural analysis of business (pp. 25-55). Cambridge: Cambridge University Press.

Pierre, J. (2005). Comparative urban governance: Comparing complex causalities. Urban Affairs Review, 40(4), $446-462$.

Rast, J. (2005). The politics of alternative economic development: Revisiting the Stone-Imbroscio debate. Journal of Urban Affairs, 27(1), 53-69.

Ratcliff, R. E. (1980). Declining cities and capitalist class structure. In G. W. Domhoff (Ed.), Power Structure Research (pp. 115-138). New York: Sage.

Roberts, B. H., \& Murray, A. T. (2002). National and regional corporate spatial structure. Annals of Regional Science, 36, 347-368.

Salmon, S., \& Leibovitz, J. (1999). 20/20 vision? Inter-urban competition, crisis and the politics of downtown development in Cincinnati, Ohio. Space and Polity, 3(2), 233-255.

Salzman, H., \& Domhoff, G. W. (1980). The corporate community and government: Do they interlock? In G. W. Domhoff (Ed.), Power Structure Research (pp. 227-254). New York: Sage.

Salzman, H., \& Domhoff, G. W. (1983). Nonprofit organizations and the corporate community. Social Science History, 7(2), 205-216.

Sbragia, A. M. (1990). Pittsburgh's "third way": The nonprofit sector as a key to urban regeneration. In D. Judd \& M. Parkinson (Eds.), Leadership and urban regeneration (pp. 51-68). Newbury Park, CA: Sage.

Schoenberger, E. (1991). The corporate interview as a research method in economic geography. Professional Geographer, 43(2), 180-189.

Schoenberger, E. (2001). Corporate autobiographies: The narrative strategies of corporate strategists. Journal of Economic Geography, 1, 277-298. 
Scott, A. J. (2006). Creative cities: Conceptual issues and policy questions. Journal of Urban Affairs, 28(1), 1-17.

Scott, J. (1991). Networks of corporate power: A comparative assessment. Annual Review of Sociology, 17, 181203.

Scott, J. (2003). Transformations in the British economic elite. Comparative Sociology, 2(1), 155-173.

Smith, H., \& Graves, W. (2005). Gentrification as corporate growth strategy: The strange case of Charlotte, North Carolina and the Bank of America. Journal of Urban Affairs, 27(4), 403-418.

Stafford, H. A. (1979). Principles of industrial facilities location. Norcross, GA: Conway Publications.

Stone, C. N. (1980). Systemic power in community decision making: A restatement of stratification theory. The American Political Science Review, 74(4), 978-990.

Stone, C. N. (1987). The study of the politics of urban development. In C. N. Stone \& H. T. Sanders (Eds.), The politics of urban development (pp. 3-22). Lawrence: University Press of Kansas.

Stone, C. N. (1989). Regime politics: Governing Atlanta, 1946-1988. Lawrence: University Press of Kansas.

Stone, C. N. (1993). Urban regimes and the capacity to govern: A political economy approach. Journal of Urban Affairs, 15(1), 1-28.

Stone, C. N. (2001). The Atlanta experience re-examined: The link between agenda and regime change. International Journal of Urban and Regional Research, 21(1), 20-34.

Stone, C. N. (2004). It's more than the economy after all: Continuing the debate about urban regimes. Journal of Urban Affairs, 26(1), 1-19.

Stone, C. N. (2005). Looking back to look forward: Reflection on urban regime analysis. Urban Affairs Review, 40(3), 309-341.

Storper, M., \& Walker, R. (1989). The capitalist imperative: Territory, technology, and industrial growth. New York: Basil Blackwell.

Turner, R. S. (1992). Growth politics and downtown development: The economic imperative in sunbelt cities. Urban Affairs Quarterly, 28(1), 3-21.

Useem, M. (1979). The social organization of the American business elite and participation of corporation directors in the governance of American institutions. American Sociological Review, 44(4), 553-572.

Useem, M. (1980). Which business leaders help govern? In G. W. Domhoff (Ed.), Power Structure Research (pp. 199-225). New York: Sage.

Useem, M. (1984). The inner circle: Large corporations and the rise of business political activity in the U.S. and U.K. Oxford: Oxford University Press.

Van den Berg, L., Braun, E., \& Otgaar, A. H. J. (2004). Corporate community involvement in US and European cities. Environment and Planning C: Government and Policy, 22, 475-494.

Ward, K. (1996). Rereading urban regime theory: A sympathetic critique. Geoforum, 27(4), 427-438.

Westphal, J. D., \& Zajac, E. J. (1995). Who shall govern? CEO/Board power, demographic similarity, and new director selection. Administrative Quarterly, 40(1), 60-83.

Whelan, R. K. (1987). New Orleans: Mayoral politics and economic-development policies in the postwar years, 1945-1986. In C. N. Stone \& H. T. Sanders (Eds.), The politics of urban development. Lawrence: University Press of Kansas.

Whelan, R. K., \& Young, A. H. (1991). New Orleans: The ambivalent city. In H. V. Savitch \& J. C. Thomas (Eds.), Big city politics in transition (pp. 132-148). Newbury Park, CA: Sage.

Whelan, R. K., Young, A. H., \& Lauria, M. (1994). Urban regimes and racial politics in New Orleans. Journal of Urban Affairs, 16(1), 1-21.

Whitt, J. A. (1987). Mozart in the metropolis: The arts coalition and the urban growth machine. Urban Affairs Review, 23(1), 15-36.

Whitt, J. A. (1988). The role of the performing arts in urban competition and growth. In S. Cummings (Ed.), Business elites and urban development (pp. 49-70). Albany: State University of New York Press. 